Vol. 15 (2006): 166-182.

\title{
Weed occurrence in Finnish coastal regions: a survey of organically cropped spring cereals
}

\author{
Paul Riesinger \\ Department of Applied Biology, FI-00014 University of Helsinki, Finland, present address: Edenkatu 5, \\ FI-10300 Karjaa, Finland, e-mail: paul.riesinger@sydvast.fi \\ Terho Hyvönen \\ MTT Agrifood Research Finland, Plant Production Research, FI-31600 Jokioinen, Finland
}

\begin{abstract}
Weed communities of organically cropped spring cereal stands in the southern and the northwestern coastal regions of Finland (= south and northwest, respectively) were compared with respect to number of species, frequency of occurrence, density and dry weight. Regional specialization of agricultural production along with differences in climate and soil properties were expected to generate differences in weed communities between south and northwest. Total and average numbers of species were higher in the south than in the northwest (33 vs. 26 and 15.6 vs. 10.0, respectively). Some rare species (e.g. Papaver dubium) were found in the south. Fumaria officinalis and Lamium spp. were found only in the south. The densities and dry weights of Lapsana communis, Myosotis arvensis, Polygonum aviculare, Tripleurospermum inodorum and Vicia spp. were higher in the south, while the densities and dry weights of Elymus repens, Persicaria spp. and Spergula arvensis were higher in the northwest. Total density of weeds did not differ between south and northwest (average $=565$ vs. 570 shoots $\mathrm{m}^{-2}$, respectively). Total dry weight of weeds was higher in the northwest compared with the south (average $=1594 \mathrm{vs} .697 \mathrm{~kg} \mathrm{ha}^{-1}$, respectively), mainly due to the high dry weight of $E$. repens. The only variable that was dependent on the duration of organic farming was weed density in the south. The abundance of nitrophilous in relation to non-nitrophilous weed species was higher while the abundance of perennial ruderal and grassland weed species was lower compared with previous weed surveys. This can be regarded as the result of increasing cropping intensity on organic farms in Finland. Different weed communities call for the application of specific target-oriented weed management in the respective coastal regions.
\end{abstract}

Key words: cereals, coastal regions, farm case studies, Finland, organic farming, weed flora, weed management, weed occurrence 
Vol. 15 (2006): 166-182.

\section{Introduction}

Weed community composition and weed abundance are influenced by climate and soil properties, thus leading to regional differences. The development of regional differences in arable weed communities is further affected by specialization of agricultural production, changes in production intensity and conversion to alternative farming concepts (El Titi 1995, Mäder et al. 2002). In Finland, this development has been studied by recurrent weed surveys.

In the first national weed survey carried out in Finland, Mukula et al. (1969) attributed geographical differences of frequency of occurrence and abundance of weed species to differences in climate and soil properties. Since the 1960 s, mechanization and specialization have brought with them a decline in the number of farm enterprises in Finland. As a result of regional specialization, stockless crop husbandry has become predominant in southern Finland, while animal husbandry prevails in central, eastern and northwestern Finland. At the same time, the crop rotations have become more monotonous and production has been intensified (National Board of Agriculture 1991, Information Centre of the Ministry of Agriculture and Forestry 2003). Commenting on the second national weed survey, Erviö and Salonen (1987) pointed out that the weed flora composition in conventionally cropped fields was changing due to interacting factors related to the intensification of crop production.

Since 1991 when a financial support program for organic agriculture was launched in Finland, the area devoted to organic agriculture has increased from $0.3 \%$ (1991) to $7.0 \%$ (2002) of the total area of arable land. In 2002, $6.8 \%$ of all active farms in Finland were acknowledged as organic farms (Plant Production Inspection Centre 2003). Both conventional and organic farms in Finland strive for advantages of scale, i.e. increase in size of arable land, specialization on a few branches of production and high proportions of cash crops (Plant Production Inspection Centre 2003).

Monotonous crop rotations along with fertilization and application of herbicides have been found to be detrimental to the species diversity of weed communities. Monotonous crop rotations contribute to a decrease in weed species richness (Hald 1999, Leeson et al. 2000). However, out of all agricultural management practices, the application of herbicides exerts the largest influence on weed species diversity and abundance (Doucet et al. 1999, Hyvönen and Salonen 2001). In Finland, the application of herbicides on agricultural land started to increase after the first nation-wide weed survey was carried out 1961-1964 (Mukula et al. 1969). Another measure that has a selective impact on weed species is seed cleaning (Svensson and Wigren 1986). Intensive soil cultivation, on the other hand, leads to a more general decline of weed species diversity and abundance (Cardina et al. 1991, Frick and Thomas 1992). High soil nutrient levels favour shade-tolerant and competitive weed species (Ellenberg et al. 1991, Blackshaw et al. 2003) but suppress others and lead generally to a decrease of weed species diversity and abundance (Erviö 1972, Pyšek and Lepš 1991).

Organic farming has been found to support populations of rare and threatened weed species (Rydberg and Milberg 2000) and to contribute to larger species diversity (Hald 1999, Hyvönen and Salonen 2001, Hyvönen et al. 2003). However, organic farming per se does not necessarily contribute to higher species diversity. In fact, intensification of weed management on organic farms has been observed to have a negative impact on weed species diversity (van Elsen 2000). A combination of intensive tillage, high soil nutrient status, highyielding crop varieties and efficient mechanical weed control may result in organically managed crops that are highly competitive in relation to the weed flora (Albrecht and Mattheis 1998). Legumerich leys, grain legumes and legume-cereal intercrops provide symbiotically fixed nitrogen (Jensen 1986, Nykänen et al. 2000). In some cases large amounts of manure are transferred from conventional to organic farms.

Weed abundance in organically cultivated crop stands has been found to be higher than in conventionally cropped stands (Leeson et al. 2000, Salonen et al. 2001a). Salonen et al. (2001b) emphasized that the spreading of especially Chenopodi- 
um album, Cirsium arvense, Elymus repens and Sonchus arvensis might seriously threaten the further adoption of organic farming in Finland. Lack of understanding of the specific features of an organic cropping system may cause a rapid increase of weed infestation (Rantzau et al. 1990, Freyer 1991). On the other hand, Mela (1988), surveying pioneer farms of organic agriculture in Finland, found that weed biomass decreased as a function of the period of organic production (while weed density increased). According to Davies et al. (1997), a rapid increase of weed density and weed seedbank numbers during the first years of conversion might be followed by a stabilization, provided that ley and intensively managed horticultural crops make up a part of the crop rotation. After all, the management skills of the farmer are decisive for the level of weed infestation (Rasmussen et al. 1998).

Owing to the geographical differences in weed flora composition and abundance found in the first national weed survey carried out in Finland, Mukula et al. (1969) proposed a floristic division of Finland into different zones, among others the southwestern archipelago and the northwestern region along the Gulf of Bothnia. The following two national weed surveys concentrated on the inland regions of Finland (Erviö and Salonen 1987, Salonen et al. 2001a). Salonen et al. (2001a) confirmed the contribution of the regional specialization of plant cropping to the differences between weed floras in the southern and southwestern regions as well as between the central and eastern regions. However, the impact of specialization and intensification on the weed floras in the southern and the northwestern coastal regions remains to be investigated. Nothing is known about the impact of organic cropping practices on the weed communities of the Finnish coastal regions since the 1980s (Mela 1988).

This study aims to supplement the latest national survey of weed occurrence (Salonen et al. 2001a, b) by investigating organically cropped spring cereal stands in the southern and the northwestern coastal regions. Weed communities were expected to differ from each other due to different geographical location and regional specialization of agricultural production. Furthermore, it was ex- pected that the weed community composition in the coastal regions would differ from that of the inland regions. As a result of specialization and intensified production methods, weed communities in organically cropped spring cereal stands along the Finnish coast were expected to be less diverse and less abundant than the weed communities that had been recorded in these regions in conventionally cropped spring cereals 1961-1964 (Mukula et al. 1969) and in organically cropped cereal stands 1984-1986 (Mela 1988). Organic farms in the coastal regions were expected to differ from each other with regard to weed abundance, depending not only on climatic and edaphic conditions but also on agricultural management.

\section{Material and methods}

\section{Study area, farms and fields}

Weed communities in organically cropped spring cereal stands were studied by a survey that was carried out 2002. The fields were located along the Gulf of Finland in the south, in the southwestern archipelago and along the Gulf of Bothnia in the northwest. The southern coastal region includes the districts of Itä-Uusimaa, Uusimaa, VarsinaisSuomi and Ahvenanmaa (hereafter = south). The northwestern coastal region covers the district of Pohjanmaa (hereafter $=$ northwest). The investigated coastal regions stretch from about $60^{\circ}$ to $65^{\circ}$ North and differ from each other with regard to climate, soil properties and branches of production. Precipitation is lower and soil types differ in the coastal regions compared with the adjacent inland regions (Kurki 1982, Mukula and Rantanen 1987, Finnish Meteorological Institute 2003).

Thirty farms managed according to the regulations of organic farming (European Council 1991, 1999) were selected with the help of the regional extension services. Farm and field data are specified in Table 1. The large geographical area covered by this study and limitations with respect to labour advocated a restricted sample size. 
Vol. 15 (2006): 166-182.

Table 1. Farm and field data.

\begin{tabular}{|c|c|c|}
\hline & $\begin{array}{c}\text { Southern } \\
\text { coastal region }\end{array}$ & $\begin{array}{l}\text { Northwestern } \\
\text { coastal region }\end{array}$ \\
\hline Number of fields ${ }^{\text {a }}$ & 18 & 12 \\
\hline \multicolumn{3}{|l|}{ Branch of production } \\
\hline animal husbandry & 9 & 7 \\
\hline crop husbandry & 9 & 5 \\
\hline \multicolumn{3}{|c|}{$\begin{array}{l}\text { Proportion of ley or fallow } \\
\text { in rotation, } \%\end{array}$} \\
\hline $10-29$ & 5 & 5 \\
\hline $30-39$ & 2 & 6 \\
\hline $40-70$ & 11 & 1 \\
\hline \multicolumn{3}{|c|}{$\begin{array}{l}\text { Proportion of winter cereals } \\
\text { in rotation, } \%\end{array}$} \\
\hline $0-10$ & 3 & 1 \\
\hline $11-20$ & 4 & 2 \\
\hline $21-30$ & 4 & - \\
\hline$>30$ & 1 & - \\
\hline \multicolumn{3}{|l|}{ Soil type ${ }^{b}$} \\
\hline clay & 13 & 3 \\
\hline silt & 3 & 4 \\
\hline sand & 2 & 3 \\
\hline organic & - & 2 \\
\hline \multicolumn{3}{|l|}{ Year of conversion $^{c}$} \\
\hline 1981-1990 & 1 & 2 \\
\hline 1991-1995 & 10 & 5 \\
\hline 1996-2000 & 7 & 5 \\
\hline \multicolumn{3}{|l|}{ Cereal crop } \\
\hline wheat & 13 & 4 \\
\hline barley & 1 & 3 \\
\hline oats & 3 & 3 \\
\hline mixture & 1 & 2 \\
\hline
\end{tabular}

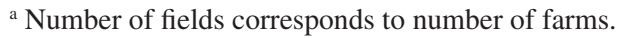

${ }^{\mathrm{b}}$ Humus contents varied between $3-5.9 \%$ in most of the clay and silt soils, between $6-11.9 \%$ in some clay, silt and sand soils and between $12-19.9 \%$ in a few clay and silt soils. The organic soils investigated in northern Pohjanmaa contain 20-39.9\% humus and are classified as mull soils.

${ }^{c}$ Year of conversion refers to the surveyed field.

The farms participating in this survey cultivated on average 67.7 ha of arable land (median = $53.3 \mathrm{ha}$ ) whereas the average Finnish organic farm comprised 30.9 ha of arable land (Plant Production Inspection Centre 2003). Sixteen out of the 30 farms were engaged in animal husbandry. However, 10 out of the 14 stockless farms imported animal manure from other farms situated in their neighbourhood. Animal husbandry farms and stockless farms were not evenly distributed along the coastal regions but reflected structural differences similar to the regional distribution of conventional farms. In the south as well as in the southernmost part of the northwest, the farms were mainly stockless or kept beef cattle, while all farms in the northern part of the northwestern region specialized in milk production.

On every farm, one field cropped with spring cereals was randomly selected. Fields were not chosen to be representative of the respective farms. Instead, the objective was to establish samples of weed communities characteristic of the southern and the northwestern coastal regions, respectively. Pure stands of spring wheat, oats or barley were preferred. In five cases no pure stand of spring cereals was grown and a crop with undersown ley was therefore chosen. The average size of the fields was 3.2 ha (median $=2.3$ ha), with a range between 0.5-11.0 ha. Soil data were derived from samples taken by the farmers and analyzed according to the routines described by Vuorinen and Mäkitie (1955).

With the exception of one field, primary tillage had been carried out by ploughing. Stubble cultivation with spring-tine cultivators had been carried out in 6 out of 30 fields prior to ploughing. Twenty-four fields had been ploughed during autumn while 5 fields had been ploughed in spring. Spring cereals had been sown during April on Ahvenanmaa, during the first half of May in the other southern districts, and during the second half of May in the northwest. Weed harrowing was applied in 5 out of 30 cereal stands.

\section{Weather conditions}

The growing period in the study year (calculated in days when the base temperature of $5^{\circ} \mathrm{C}$ was exceeded) lasted 163 days in the south and 148 days in the northwest. The effective temperature sum (calculated in degree days accumulated above the 
base temperature of $5^{\circ} \mathrm{C}$, DD5) reached 1536$1693^{\circ} \mathrm{C}$ in the south and $1405-1499^{\circ} \mathrm{C}$ in the northwest. Precipitation during April, May, June and July varied from $117.7 \mathrm{~mm}$ to $275.9 \mathrm{~mm}$ in the different districts included in the survey. Precipitation was generally lower at the south coast than in the inner parts of the southern districts or in the northwest. Compared with the average data of the latest 30 years period, the growing period in 2002 was characterized by a high effective temperature sum. Precipitation was low in April and May but high in June and July (Finnish Meteorological Institute 2003). The investigation comprised of only one year but included different climatic zones, different soil types and different management systems.

\section{Sampling}

Number of weed species (species $\mathrm{m}^{-2}$ ), weed density $\left(\right.$ shoots $\left.\mathrm{m}^{-2}\right)$ as well as dry weights $\left(\mathrm{g} \mathrm{m}^{-2}\right)$ of crop and weed species were assessed at the stage when both weeds and crop had reached their maximum biomass, i.e. at DC (decimal code) 70-79 on the scale of Zadoks et al. (1974). Because the fields were situated along the coastline from the southeast to the northwest, sampling could be conducted within a narrow range of crop development stages.

Due to the plentiful occurrence of weeds and limitations with respect to labour, sampling was restricted to four plots per field. The sampling plots were chosen by dividing the longest diagonal across the field into five even distances. Headland, shallow sites suffering from drought, compacted sites or sites close to artesian springs were avoided. Sampling was carried out with a rectangular metal frame measuring $0.25 \mathrm{~m}^{2}$. The frame was placed so that the distance from crop row to frame was the same both in the upper and lower margin of the frame. Crop and weed species were cut at soil surface, sorted by species, counted and dried in paper bags. The samples were dried by airflow dryer at $30-40^{\circ} \mathrm{C}$. The samples were weighed to the nearest $0.1 \mathrm{~g}$. Density and dry weight were used as measures of weed abundance.

\section{Assessment of weed species}

The plant species nomenclature follows that of Hämet-Ahti et al. (1998). The full scientific names with attributions together with the BAYER codes of weeds (Bayer 1992) are given in Table 2. Species that could not be identified were pooled by genera and taxa. Individuals belonging to the taxa Brassica spp., Chenopodium spp., Galeopsis spp., Galium spp., Lamium spp., Persicaria spp., Rumex spp., Taraxacum spp., Trifolium spp., Veronica spp. and Vicia spp. were not identified to species level. Only few individuals of the species Matricaria matricaroides (LESS.) PORT. and Matricaria recutita $\mathrm{L}$. were found, and these were therefore included in the species Tripleurospermum inodorum (L.) SCH. BIP.; likewise, Viola arvensis includes V. tricolor. Grasses other than Elymus repens were treated as one taxon. Although ley grasses and Trifolium species in pure stands of cereals cannot be considered to be part of the crop, they were not regarded as weeds with respect to weed density. The competitive potential of ley species was expressed by including the biomass of ley species either into the weed biomass or, in the case of undersown ley seed, into the biomass of the nurse crop.

\section{Analyses of the data}

The Wilcoxon two-sample test (see Sokal and Rohlf 1995) was applied to compare average numbers of species, densities and dry weights of crop and weeds as well as single weed species between the southern and the northwestern regions. The relationship between the duration of organic farming and the number of species, the density, and the dry weight of weeds was studied by linear regression in both regions separately. For this purpose, density and dry weight data were $\log (x+1)$ transformed.

Since the number of sampled fields varied between south and northwest, the total species numbers of these regions could not be compared. The expected number of species $E\left(S_{n}\right)$ for each region was therefore calculated by rarefaction. In rarefac- 
Vol. 15 (2006): 166-182.

tion, the number of species of larger samples is scaled down to a given number of individuals that permits the comparison of the numbers of species between samples differing in size:

$$
E\left(S_{n}\right)=\sum_{i=1}^{S}\left(1-\frac{\left(\begin{array}{c}
N-N_{i} \\
n
\end{array}\right)}{\left(\begin{array}{l}
N \\
n
\end{array}\right)}\right),
$$

where $\mathrm{E}\left(\mathrm{S}_{\mathrm{n}}\right)=$ the expected number of species in a random sample of $n$ individuals, $S=$ the total number of species in the entire collection, $\mathrm{N}_{\mathrm{i}}=$ the number of individuals per species $\mathrm{i}, \mathrm{N}=$ the total number of individuals in the collection, and $\mathrm{n}=$ the sample size (number of individuals) chosen for standardization (see Heck et al. 1975, Krebs 1999). Sample size was scaled down to 6500 individuals (the number of individuals was 6839 in the northwest), and standard deviations were calculated for each sample size. For the analysis, data were pooled across fields.

\section{Results}

\section{Frequency of occurrence}

Certain species such as Capsella bursa-pastoris, Fumaria officinalis, Lamium spp., Plantago major, Stachys palustris and Thlaspi arvense were found only in the southern coastal region while others, i.e. Achillea millefolium, Achillea ptarmica, Leontodon autumnalis and Rumex spp. occurred only in the northwestern coastal region (Table 2). The weed species Brassica spp., Galium spp., Lapsana communis, Myosotis arvensis, Polygonum aviculare, Tripleurospermum inodorum, Vicia spp. and Viola arvensis were more common in the south, while Galeopsis spp., Persicaria spp. and Spergula arvensis were more common in the northwest (Table 2). Among the perennial weed species, Elymus repens was somewhat more frequent in the northwest, while Cirsium arvense and Sonchus arvensis were more frequent in the south (Table 2). Chenopodium spp., E. repens and Stel- laria media were very common in both regions (Table 2).

\section{Number of weed species}

A total of 38 weed species and weed taxa were found in the coastal regions. Both the observed $\left(\mathrm{S}_{\mathrm{OBS}}\right)$ and expected $\left(\mathrm{E}\left(\mathrm{S}_{6500}\right)\right)$ total number of species were higher in the south than in the northwest: 33 and 31.8 ( $\mathrm{SD}=0.91$ ) vs. 26 and 25.9 ( $\mathrm{SD}=$ 0.23 ), respectively. The same pattern was found with regard to the average number of species per field. The average number of species in the south and northwest was 15.6 vs. 10.0 (median $=16.0$ vs. 9.5; $\mathrm{SD}=3.2$ vs. 3.2$)$, respectively $(\mathrm{Z}=-3.63 ; \mathrm{P}<$ $0.001)$. Some of the species that were found are considered rare, i.e. Anchusa arvensis, Centaurea cyanus and Erodium cicutarium or extinct, i.e. $\mathrm{Pa}$ paver dubium (Hämet-Ahti et al. 1998, Rassi et al. 2001). The number of weed species was not dependent on the duration of organic farming in either region (south: $\mathrm{R}^{2}=0.11, \mathrm{P}=0.186$; northwest: $\left.\mathrm{R}^{2}=0.005, \mathrm{P}=0.835\right)$.

\section{Abundance of single weed species}

The most frequent species were generally most abundant with respect to density and dry weight. The only exception was Sonchus arvensis, which was more prominent in the northwest with respect to dry weight than could be deduced from frequencies and densities. Weed abundance in the south differed from the northwest with respect to density and dry weight. The densities of Lapsana communis, Myosotis arvensis, Polygonum aviculare, Sonchus arvensis, Tripleurospermum inodorum and Vicia spp. were significantly higher in the south, whereas E. repens, Persicaria spp. and Spergula arvensis (at the limit of significance) occurred at significantly higher densities in the northwest (Table 3). Dry weights of L. communis, Myosotis arvensis (at the limit of significance), Polygonum aviculare, Tripleurospermum inodorum and Vicia spp. (at the limit of significance) were significantly higher in the south, while E. repens, Galeopsis 
Riesinger, P. \& Hyvönen, T. Weed occurrence in coastal regions of Finland

Table 2. Frequencies of all weed species and weed taxa found in the southern and the northwestern coastal regions.

\begin{tabular}{|c|c|c|c|c|}
\hline Weed species and taxa & $\begin{array}{l}\text { BAYER } \\
\text { code }^{\text {a }}\end{array}$ & Both regions & $\begin{array}{c}\text { Southern } \\
\text { coastal region }\end{array}$ & $\begin{array}{l}\text { Northwestern } \\
\text { coastal region }\end{array}$ \\
\hline Achillea millefolium $\mathrm{L}$. & ACHMI & 3.3 & - & 8.3 \\
\hline Achillea ptarmica $\mathrm{L}$. & ACHPT & 3.3 & - & 8.3 \\
\hline Anchusa arvensis (L.) MB & ANCHA & 3.3 & 5.6 & - \\
\hline Brassica L. spp. & BRASS & 20.0 & 27.8 & 8.3 \\
\hline Capsella bursa-pastoris (L.) MEDIK. & CAPBP & 23.3 & 38.9 & - \\
\hline Centaurea cyanus L. & CENCY & 3.3 & 5.6 & - \\
\hline Chenopodium L. spp. & CHESS & 96.7 & 100.0 & 91.7 \\
\hline Cirsium arvense (L.) SCOP. & CIRAR & 16.7 & 22.2 & 8.3 \\
\hline Elymus repens (L.) GOULD & AGRRE & 83.3 & 77.8 & 91.7 \\
\hline Equisetum arvense $\mathrm{L}$. & EQUAR & 26.7 & 33.3 & 16.7 \\
\hline Erodium cicutarium (L.) L HÈR. & EROCI & 3.3 & 5.6 & - \\
\hline Erysimum cheiranthoides $\mathrm{L}$. & ERYCH & 73.3 & 72.2 & 75.0 \\
\hline Fallopia convolvulus (L.) Á. LÖVE & POLCO & 60.0 & 66.7 & 50.0 \\
\hline Fumaria officinalis L. & FUMOF & 43.3 & 72.2 & - \\
\hline Galeopsis L. spp. & GAESS & 76.7 & 66.7 & 91.7 \\
\hline Galium L. spp. & GALSS & 56.7 & 66.7 & 41.7 \\
\hline Gnaphalium uliginosum $\mathrm{L}$. & GNAUL & 3.3 & - & 8.3 \\
\hline Grasses other than Elymus repens (L.) GOULD ${ }^{\text {b }}$ & - & 46.7 & 27.8 & 75.0 \\
\hline Lamium L. spp. & LAMSS & 43.3 & 72.2 & - \\
\hline Lapsana communis $\mathrm{L}$. & LAPCO & 56.7 & 88.9 & 8.3 \\
\hline Leontodon autumnalis $\mathrm{L}$. & LEBAU & 3.3 & - & 8.3 \\
\hline Myosotis arvensis (L.) HILL & MYOAR & 50.0 & 72.2 & 16.7 \\
\hline Papaver dubium L. & PAPDU & 3.3 & 5.6 & - \\
\hline Persicaria L. spp. & POLLA & 63.3 & 44.4 & 91.7 \\
\hline Plantago major $\mathrm{L}$. & PLAMA & 6.7 & 11.1 & - \\
\hline Polygonum aviculare $\mathrm{L}$. & POLAV & 56.7 & 72.2 & 33.3 \\
\hline Ranunculus repens $\mathrm{L}$. & RANRE & 20.0 & 11.1 & 33.3 \\
\hline Rumex L. spp. & RUMSS & 6.7 & - & 16.7 \\
\hline Sonchus arvensis L. & SONAR & 56.7 & 77.8 & 25.0 \\
\hline Spergula arvensis L. & SPRAR & 66.7 & 61.1 & 75.0 \\
\hline Stachys palustris L. & STAPA & 3.3 & 5.6 & - \\
\hline Stellaria media (L.) VILL. & STEME & 96.7 & 100.0 & 91.7 \\
\hline Taraxacum L. spp. & TAROF & 23.3 & 33.3 & 8.3 \\
\hline Thlaspi arvense $\mathrm{L}$. & THLAR & 16.7 & 27.8 & - \\
\hline Trifolium L. spp. ${ }^{\mathrm{b}}$ & TRFSS & 66.7 & 66.7 & 66.7 \\
\hline Tripleurospermum inodorum SCH. BIP. & MATSS & 53.3 & 72.2 & 25.0 \\
\hline Tussilago farfara $\mathrm{L}$. & TUSFA & 3.3 & 5.6 & - \\
\hline Veronica L. spp. & VERSS & 3.3 & 5.6 & - \\
\hline Vicia L. spp. & VICSS & 30.0 & 44.4 & 8.3 \\
\hline Viola arvensis MURRAY & VIOAR & 76.7 & 88.9 & 58.3 \\
\hline
\end{tabular}

a Bayer codes (BAYER 1992).

${ }^{\mathrm{b}}$ Not included in the number of weed species. 
Vol. 15 (2006): 166-182.

Table 3. Mean densities and dry weights of the weed species dominating in the southern and the northwestern coastal regions including statistical differences between regions.

\begin{tabular}{|c|c|c|c|c|c|c|c|c|}
\hline & \multicolumn{2}{|c|}{$\begin{array}{c}\text { Density } \\
\left(\text { shoots } \mathrm{m}^{-2}\right)\end{array}$} & \multirow[t]{2}{*}{$\mathrm{Z}^{\mathrm{a}}$} & \multirow[t]{2}{*}{ P-value } & \multicolumn{2}{|c|}{$\begin{array}{c}\text { Dry weight } \\
\left(\mathrm{kg} \mathrm{ha}^{-1}\right)\end{array}$} & \multirow[t]{2}{*}{$\mathrm{Z}^{\mathrm{a}}$} & \multirow[t]{2}{*}{ P-value } \\
\hline & South & Northwest & & & South & Northwest & & \\
\hline Brassica spp. & 5.6 & 0.1 & -1.36 & 0.173 & 61.6 & 0.2 & -1.39 & 0.164 \\
\hline Chenopodium spp. & 156.3 & 99.8 & -1.06 & 0.290 & 171.9 & 299.7 & 1.25 & 0.212 \\
\hline Cirsium arvense & 0.6 & 0.2 & -0.95 & 0.344 & 3.2 & 0.1 & -1.01 & 0.312 \\
\hline Elymus repens & 56.1 & 212.1 & 2.25 & 0.025 & 101.6 & 882.3 & 2.61 & 0.009 \\
\hline Erysimum cheiranthoides & 23.5 & 17.4 & 1.43 & 0.152 & 13.1 & 20.6 & 1.62 & 0.104 \\
\hline Fallopia convolvulus & 27.7 & 2.5 & -1.51 & 0.131 & 45.1 & 7.0 & -1.36 & 0.175 \\
\hline Fumaria officinalis & 5.3 & - & -3.64 & 0.001 & 11.6 & - & -3.42 & 0.002 \\
\hline Galeopsis spp. & 20.4 & 32.7 & 1.60 & 0.110 & 29.1 & 93.3 & 2.62 & 0.009 \\
\hline Galium spp. & 10.0 & 4.4 & -1.39 & 0.174 & 23.7 & 6.4 & -1.67 & 0.108 \\
\hline Lamium spp. & 24.1 & - & -3.63 & $<0.001$ & 31.6 & - & -3.42 & 0.001 \\
\hline Lapsana communis & 33.0 & 0.3 & -4.02 & $<0.001$ & 15.9 & 0 & -4.13 & $<0.001$ \\
\hline Myosotis arvensis & 13.6 & 0.25 & -3.12 & 0.004 & 3.9 & 0.4 & -2.01 & 0.054 \\
\hline Persicaria spp. & 6.2 & 19.8 & 2.07 & 0.038 & 5.4 & 32.9 & 2.76 & 0.006 \\
\hline Polygonum aviculare & 4.5 & 0.9 & -2.19 & 0.036 & 4.1 & 1.3 & -2.05 & 0.049 \\
\hline Sonchus arvensis & 19.7 & 3.7 & -2.78 & 0.005 & 35.6 & 38.2 & 2.39 & 0.020 \\
\hline Spergula arvensis & 19.7 & 120.0 & 1.96 & 0.050 & 5.7 & 122.1 & 2.02 & 0.044 \\
\hline Stellaria media & 50.2 & 28.3 & -1.74 & 0.082 & 43.3 & 24.1 & -0.91 & 0.363 \\
\hline $\begin{array}{l}\text { Tripleurospermum } \\
\text { inodorum }\end{array}$ & 16.6 & 0.3 & -2.93 & 0.007 & 10.5 & 0.03 & -2.74 & 0.011 \\
\hline Vicia spp. & 6.8 & 0.3 & -2.01 & 0.044 & 22.9 & 0.3 & -2.04 & 0.051 \\
\hline Viola arvensis & 43.5 & 16.9 & -0.68 & 0.495 & 10.6 & 6.9 & -0.30 & 0.765 \\
\hline
\end{tabular}

${ }^{a}$ Wilcoxon test statistic.

spp., Persicaria spp., Sonchus arvensis and Spergula arvensis had higher dry weights in the northwest (Table 3).

More weed species dominated in the south than in the northwest. In the south, eight weed species and taxa (Chenopodium spp., E. repens, S. media, $V$. arvensis, L. communis, $F$. convolvulus, Lamium spp., E. cheiranthoides; ranked in descending order) made up $73.3 \%$ of total weed density, while in the northwest only three species and taxa (E. repens, Spergula arvensis, Chenopodium spp.; ranked in descending order) were required to reach $75.7 \%$ of total weed density (Fig. 1).

$70.4 \%$ of the total weed dry weight in the south consisted of seven species and taxa (Chenopodium spp., E. repens, Brassica spp., F. convolvulus, $S$. media, Sonchus arvensis, Lamium spp.; ranked in descending order), while only two species (E. repens, Chenopodium spp.; ranked in descending order) made up $74.1 \%$ of the total weed dry weight in the northwest (Fig. 2).

\section{Abundance of crop and weeds}

Crop density was significantly higher in the south than in the northwest whereas crop dry weight did not differ between the regions (Table 4). Density of annual weed species did not differ between south and northwest whereas perennial weeds occurred at significantly higher density in the northwest (Table 4). Due to the high abundance of perennial species, weed dry weight was significantly higher in the northwest than in the south (Table 4). 
Riesinger, P. \& Hyvönen, T. Weed occurrence in coastal regions of Finland

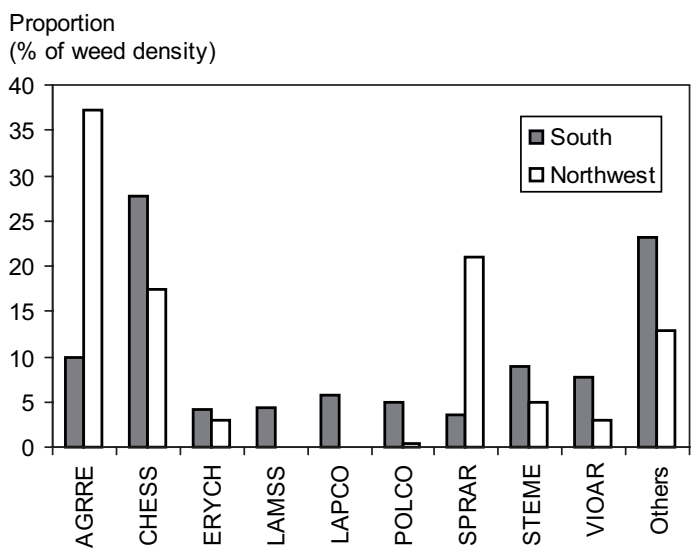

Fig. 1. Proportional density of the weed species and taxa dominating in the southern and the northwestern coastal regions. AGRRE = Elymus repens, $\mathrm{CHESS}=$ Chenopodi um spp., ERYCH = Erysimum cheiranthoides, LAMSS = Lamium spp., LAPCO = Lapsana communis, POLCO = Fallopia convolvulus, SPRAR = Spergula arvensis, STEME = Stellaria media, $\mathrm{VIOAR}=$ Viola arvensi

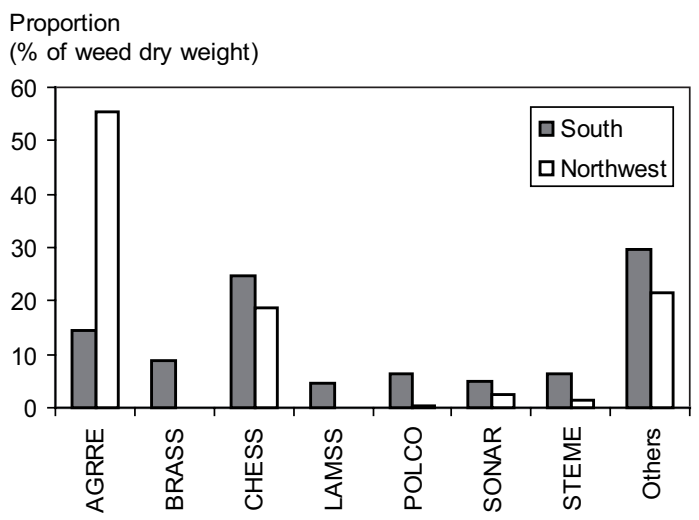

Fig. 2. Proportional dry weight of the weed species and taxa dominating in the southern and the northwestern coastal regions. AGRRE $=$ Elymus repens, BRASS = Brassica spp., CHESS = Chenopodium spp., LAMSS = Lamium spp., POLCO = Fallopia convolvulus, $\mathrm{SONAR}=$ Sonchus arvensis, STEME = Stellaria media

Table 4. Mean densities and dry weights of crop and weeds in the southern and the northwestern coastal regions including statistical differences between regions.

\begin{tabular}{|c|c|c|c|c|c|c|c|c|}
\hline & \multicolumn{3}{|c|}{ South } & \multicolumn{3}{|c|}{ Northwest } & \multirow[b]{2}{*}{$\mathrm{Z}^{\mathrm{a}}$} & \multirow[b]{2}{*}{$\mathrm{P}$-value } \\
\hline & Mean & Median & SD & Mean & Median & $\mathrm{SD}$ & & \\
\hline \multicolumn{9}{|c|}{ Density (shoots $\mathrm{m}^{-2}$ ) } \\
\hline Crop & 685.1 & 657.5 & 205.5 & 527.7 & 505.5 & 153.2 & -2.27 & 0.026 \\
\hline \multicolumn{9}{|l|}{ Weeds } \\
\hline all species & 565.4 & 467.5 & 437.4 & 569.9 & 507.5 & 334.4 & 0.32 & 0.751 \\
\hline annuals & 483.1 & 363.5 & 399.5 & 344.2 & 255.5 & 264.8 & -1.12 & 0.236 \\
\hline perennials & 82.3 & 44.0 & 115.6 & 225.8 & 190.0 & 196.5 & 2.18 & 0.029 \\
\hline \multicolumn{9}{|c|}{ Dry weight $\left(\mathrm{kg} \mathrm{ha}^{-1}\right)$} \\
\hline Crop & 6183.0 & 6564.7 & 2112.0 & 6685.4 & 6533.1 & 2390.2 & 0.15 & 0.882 \\
\hline \multicolumn{9}{|l|}{ Weeds } \\
\hline all species & 696.7 & 480.4 & 573.0 & 1594.1 & 1476.5 & 974.0 & 2.65 & 0.008 \\
\hline annuals & 521.7 & 328.1 & 504.4 & 615.4 & 494.3 & 379.2 & 1.55 & 0.122 \\
\hline perennials & 175.0 & 98.1 & 189.3 & 978.8 & 758.9 & 868.9 & 2.60 & 0.009 \\
\hline
\end{tabular}

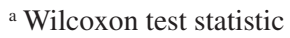

$\mathrm{SD}=$ standard deviation

Average weed density in relation to weed and crop density was 41.6 vs. $48.7 \%$ in the south compared with the northwest while the average proportion of weed dry weight in relation to total weed and crop dry weight was 11.4 vs. $20.6 \%$, respec- tively. The high abundance of perennial weed species in the northwest was due to E. repens. On average, E. repens constituted 4.3 vs. $18 \%$ of the total crop and weed density and 1.8 vs. $10.8 \%$ of the average total crop and weed dry weight in the south 
Vol. 15 (2006): 166-182.

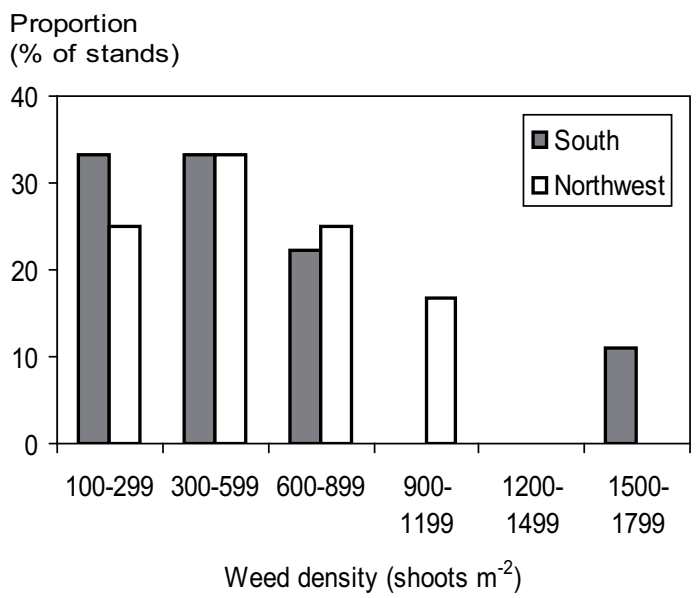

Fig. 3. Distribution of cereal stands in the southern and the northwestern coastal regions with regard to weed density.

and northwest, respectively. In some crop stands $E$. repens was not found at all while in certain crop stands it made up close to $30 \%$ of the total dry weight.

\section{Distribution of weed abundance}

The spring cereal stands included in this survey differed remarkably from each other with regard to weed density and dry weight. In $30 \%$ of the investigated spring cereal stands, weed densities ranged between 100-299 shoots $\mathrm{m}^{-2}$. In one third of the cereal fields, the density of weeds amounted to 300-599 shoots $\mathrm{m}^{-2}$ whereas it exceeded 600 shoots $\mathrm{m}^{-2}$ in $36.7 \%$ of the crop stands. With regard to lower classes of weed density, the distribution of spring cereal fields was about the same in both regions. However, the highest levels of weed density were found in the south (Fig. 3).

The dry weight of weeds exceeded $500 \mathrm{~kg} \mathrm{ha}^{-1}$ in $63.3 \%$ of the investigated crop stands. In the south, weed dry weight in half of the fields was lower than $500 \mathrm{~kg} \mathrm{ha}^{-1}$ while it exceeded $1000 \mathrm{~kg}$ $\mathrm{ha}^{-1}$ in $27.8 \%$ of the fields. In the northwest, weed dry weights lower than $500 \mathrm{~kg} \mathrm{ha}^{-1}$ were found in only $16.7 \%$ of the spring cereal stands. Weed dry

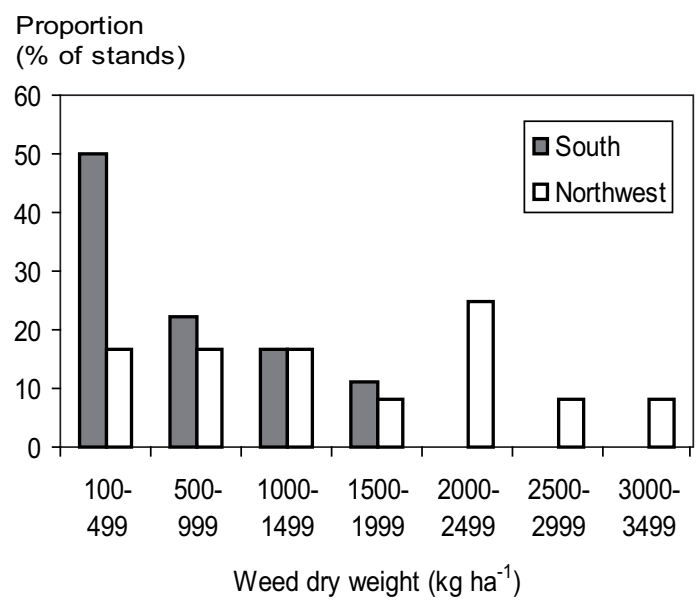

Fig. 4. Distribution of cereal stands in the southern and the northwestern coastal regions with regard to weed dry weight.

weight exceeded $1000 \mathrm{~kg} \mathrm{ha}^{-1}$ in $66.7 \%$ of the fields surveyed in the northwest (Fig. 4).

In the south, weed dry weight tended to be dependent $\left(R^{2}=0.21, P=0.055\right)$, and weed density was dependent $\left(R^{2}=0.23, P=0.042\right)$ on the duration of organic farming. In the northwest, no dependence was detected (weed dry weight: $\mathrm{R}^{2}=$ $0.02, \mathrm{P}=0.650$; weed density: $\mathrm{R}^{2}=0.029, \mathrm{P}=$ $0.598)$.

\section{Discussion}

\section{Number of weed species in the coastal regions}

The number of weed species found in the coastal regions was lower compared with the weed surveys conducted in the late 1990s (126 species found in 165 organically cropped fields; Salonen et al. 2001b), and in the early 1960s (304 species found in 2710 conventionally cropped fields; Mukula et al. 1969). The investigation by Mukula et al. (1969) covered all agricultural regions of 
Finland whereas the survey by Salonen et al. (2001b) included southern and central Finland. Since the number of species is dependent on the sample size (Heck et al. 1975), the likely reasons for the lower species number in the present study were the lower number of studied fields and the restriction to coastal regions. Furthermore, in our investigation, all weed species were not distinguished by species level, but instead pooled by genera and taxa, which underestimates the real number of weed species.

Despite of the small sample size, some rare weed species were encountered. This is in accordance with previous findings by Albrecht and Mattheis (1998). Thus, organic cropping benefits biodiversity by the conservation of rare and endangered species. The number of weed species was higher in the south than in the northwest, which is in agreement with previous investigations (Mukula et al. 1969, Salonen et al. 2001b). Weed species number in the south is enhanced by a longer growing season and a larger species pool (Hämet-Ahti et al. 1998). In agreement with Becker and Hurle (1998), the number of weed species was not related to the duration of organic farming. Rather than the duration of organic farming, the factors that determine the number of weed species include single crop management measures, such as choice of crop rotation, soil tillage, weed management, and fertilization.

In comparison with the surveys carried out by Mukula et al. (1969) and Salonen et al. (2001b), the number of dominating weed species was on the same level in the south, while it was lower in the northwest. About $70 \%$ of the total weed density had been made up by eight species in conventionally cropped spring cereals in the beginning of the 1960s (Mukula et al. 1969) and by ten species in organically cropped stands 1984-1986 (Mela 1988). This proportion was reached by the accumulated density of eight weed species in the south whereas in the northwest only three species together exceeded $70 \%$ of total weed density. Eight species had constituted $70 \%$ of the total weed dry weight recorded 1961-1964 (Mukula et al. 1969). In our investigation, the seven most dominant weed species in the south reached $70 \%$ of the total weed dry weight. In the northwest, however, this proportion of weed dry weight was made up of only two species. In the south, milder winters offer better conditions for cropping of winter cereals and thus for more diverse crop rotations whereas in the northwest fields are subjected to more simple summer cereal or ley-and-cereal rotations. Therefore, a lower number of weed species gain dominant positions in the northwest than in the south (Mukula et al. 1969, Hald 1999).

\section{Weed communities in the coastal regions}

In agreement with previous investigations (Mukula et al. 1969, Salonen et al. 2001b), regional differences in the occurrence of weed species were detected. Species preferring a warm climate such as Lamium spp. and S. palustris were only found in the south (Mukula et al. 1969, Salonen 1993). Lamium spp. and F. officinalis are known to thrive in dry clay soils (Mukula et al. 1969, Salonen 1993, Hallgren 1996). Clay soils prevail in the south, which might contribute to the fact that Lamium spp. and $F$. officinalis were found only in this region. Likewise, the significantly higher densities and dry weights of M. arvensis, P. aviculare and $T$. inodorum in the south can be explained by the preference of these weed species for dry mineral soils (Mukula et al. 1969, Erviö and Salonen 1987, Ellenberg et al. 1991, Erviö et al. 1994). On the other hand, the significantly higher abundances of Galeopsis spp. (by dry weight), Persicaria spp. and Spergula arvensis (by both density and dry weight) in the northwest are likely due to the moist coarse mineral and organic soils common in this region (Mukula et al. 1969, Salonen 1993). The tolerance of Persicaria spp. and Spergula arvensis to soils with low $\mathrm{pH}$ results in significantly higher densities and dry weights of these species in the northwest where such soils are more common than in the south. In the contrary, significantly higher abundances of weed species preferring soils with high $\mathrm{pH}$, such as Lamium spp., L. communis and $M$. arvensis were found on the clay soils of the south (Albrecht and Bachthaler 1989, Erviö et al. 1994). 
Vol. 15 (2006): 166-182.

Galeopsis spp., Persicaria spp. and Spergula arvensis are classified as summer annuals, while A. arvensis, C. cyanus, E. cicutarium, $M$. arvensis and $P$. dubium also readily germinate in autumn (Fogelfors 1977). The latter are favoured by the cultivation of winter annual crops, which is common in the south, but rather an exception in the northwest (Table 1). Brassica spp. was more frequent in the south than in the northwest, which was not expected since Salonen et al. (2001b) have not found any consistent differences between localities with regard to the occurrence of this weed taxon. Brassica spp. disseminates independently of geographical region as a volunteer crop, or through seeds contained in feed cereals that transfer to manure fertilizer. A probable reason for the relatively low occurrence of Brassica spp. in the northwest is the lower proportion of turnip rape both in conventional and organic crop rotations applied in this region (Information Centre of the Ministry of Agriculture and Forestry 2003).

In contrast to the results obtained by this survey, C. bursa-pastoris, F. officinalis and T. arvense have previously been recorded as frequent in the northwest (Mukula et al. 1969, Mela 1988, Salonen et al. 2001b). G. uliginosum, which was found in the northwest only, has been reported to occur in the south, too, although at lower frequencies than in the northwest (Mukula et al. 1969, Mela 1988, Salonen et al. 2001b). The cause for these contradictions is probably the low number of fields included in this survey.

Most of the annual weed species and seedlings of perennial species that were found in the spring cereal stands in this survey can be controlled by weed harrowing. Exceptions are Galeopsis spp. (high dry weight in the northwest) and Galium spp. (frequent both in the northwest and the south). Weed harrowing is effective against the seedling and early rosette stages of weeds and can be carried out before the emergence of the crop, as well as after DC 13 (Habel 1954, Koch 1959, Kees 1962). In contrast to weed harrowing, stubble cultivation is only effective against those weed species germinating in autumn (Boström and Fogelfors 1999). Stubble cultivation is effective against volunteer crops as well, although in the case of $B$. rapa spp. oleifera, cultivation must be shallow (Pekrun and Lutman 1998).

The perennial weed species E. repens, C. arvense and Sonchus arvensis have been regarded as the most noxious for organic cropping in Finland (Salonen et al. 2001b). C. arvense and Sonchus arvensis occurred at higher frequencies in the south compared with the northwest. The density of Sonchus arvensis was significantly higher in the south, while its dry weight was significantly higher in the northwest. Higher occurrences of these weeds in the south have previously been recorded by Mukula et al. (1969), Mela (1988) and Salonen et al. (2001b). C. arvense prefers clay soils while Sonchus arvensis also thrives in coarse mineral soils (Mukula et al. 1969, Salonen 1993). C. arvense has a deep reaching root system and therefore competes successfully with agricultural crops, especially in the dry clay soils that prevail in the south. The establishment of both $C$. arvense and Sonchus arvensis is favoured by a high proportion of annual crops (Mukula et al. 1969, Donald 1990) while cultivation of ley in combination with three cuts is an appropriate measure against $C$. arvense (Dock-Gustavsson 1997). On farms where the proportion of ley is low, C. arvense and Sonchus arvensis can be controlled by stubble cultivation, provided that tillage operations can be launched in early autumn (Boström and Fogelfors 1999).

The higher abundance of E. repens in the northwest is in line with the results obtained by the latest survey of inland sites (Salonen et al. 2001b) and is explained by the preference of this weed for moist silt and organic soils (Mukula et al. 1969, Erviö et al. 1994). Compared with the 1960s, the frequency of E. repens in fields not treated with herbicides has generally increased (cf. Mukula et al. 1969, Mela 1988, Salonen 2001b). E. repens has an extensive rhizome system and its spreading is incited by lower tillage intensity (Håkansson 2003). Stubble cultivation accomplished twice per autumn is recommended as an efficient measure against E. repens (Boström and Fogelfors 1999). However, the further to the north the fields are situated, the more limited are the opportunities for stubble cultivation after the harvest of grain crops. Cropping of late-ripening varieties further short- 
ens the period suitable for stubble cultivation. $E$. repens had previously been less frequent and less abundant in the northwest than in the south (Mukula et al. 1969, Mela 1988). More rare and less favourable opportunities for stubble cultivation than in the south have likely favoured the spreading of E. repens in the northwest. Due to the absence of tillage, the maintenance of leys for more than three years favours the spreading of E. repens (Håkansson 2003).

Differences in the occurrence of weed species between the southern and the northwestern coastal regions can thus be related to climate and edaphic as well as to management factors. Owing to the occurrence of different weed species, appropriate weed management in the south and north must rely on different strategies. In regions with short growing seasons or on organic soils, perennial weed species emerging from root shoots and rhizomes are generally restrained by integrating a spring and early summer fallow into the regular crop rotation (Bylterud 1965, Kakriainen-Rouhiainen et al. 2003).

\section{Weed abundance and cropping intensity}

Compared with previous national surveys, Chenopodium spp. in organically cropped stands reached higher abundances both in the southern and the northwestern coastal regions. The abundances of Brassica spp., F. convolvulus, Galium spp. and Lamium spp. in the south were much higher compared with previously found national average numbers. In the northwest, E. repens exceeded previously recorded average levels of density and dry weight (Mukula 1974, Mela 1988, Salonen et al. 2001b). The density of E. cheiranthoides was the same as reported at national level in the 1960s (Mukula 1974) and 1980s (Mela 1988). However, its dry weight in the northwest was twice as high.

The above mentioned weed species are either nitrophilous or, owing to their climbing growth form, competitive in conditions of increasing nitrogen levels (Mahn 1988, Albrecht and Bachthaler
1989, Ellenberg et al. 1991, Jørnsgård et al. 1996, Blackshaw et al. 2003). Of the weed species found to be more abundant in the coastal regions compared with previously recorded national average levels only C. bursa-pastoris, Spergula arvensis and Vicia spp. are non-nitrophilous (Ellenberg et al. 1991). These findings suggest higher nitrogen levels compared with the organically cropped fields investigated by previous surveys (Mela 1988, Salonen et al. 2001b) as well as compared with the conventionally cropped fields included in the first national weed survey 1961-1964 (Mukula et al. 1969). The dominance of nitrophilous weed species in organically cropped spring cereal stands in the coastal regions of Finland contradicts the prediction by Rydberg and Milberg (2000) that conversion to organic farming practices would lead to an increase of non-nitrophilous weed species. High nitrogen levels in organically cropped fields might be due to high humus levels, to frequent cropping of legumes, to recent application of manure to a single field or to regular import of nitrogen by manure acquired from other farms. High soil nitrogen levels offer a potential for high crop yields, provided that weeds are kept under control.

Frequencies of ruderal and perennial grassland weeds such as A. millefolium, A. ptarmica, E. arvense, E. cicutarium, L. autumnalis, P. major, $R$. repens, Rumex spp. and $T$. farfara were somewhat lower compared with the average national frequencies reported by Salonen et al. (2001b) and Mela (1988), and much lower than the frequencies found in the beginning of the 1960s (Mukula 1974). The decrease of these species has been attributed to land amelioration, the decline of agricultural land devoted to pasture, higher shares of annual crops, shorter duration of leys and intensified soil tillage, as well as to the application of herbicides (Erviö and Salonen 1987, Rydberg and Milberg 2000). Owing to the fundamental importance of symbiotic nitrogen fixation by red clover-grass leys for the nitrogen supply of non-leguminous crops, grassland is part of the regular crop rotation, especially on organic farms. The leys are usually terminated after two or three harvest years, tilled and grown with annual crops. A spreading of ruderal and perennial grassland weeds under organic farm- 
Vol. 15 (2006): 166-182.

ing management is therefore not to be expected. Important exceptions are $C$. arvense and $E$. repens which are adapted to soil cultivation. Consequently, the frequencies and abundances of these species have increased.

Weed density in the coastal regions was on about the same level as reported in previous national surveys of low-input conventional and organic farming (Mukula et al. 1969: 550 shoots $\mathrm{m}^{-2}$; Mela 1988: 505 shoots $\mathrm{m}^{-2}$; Salonen et al. 2001b: 469 shoots $\left.\mathrm{m}^{-2}\right)$. Average weed dry weight found in the south $\left(697 \mathrm{~kg} \mathrm{ha}^{-1}\right)$ exceeded the national average found in the 1980s (Mela 1988: $575 \mathrm{~kg} \mathrm{ha}^{-1}$ ), but was on the same level as found by the recent national survey of organically cropped spring cereal fields (Salonen et al. 2001b: $678 \mathrm{~kg} \mathrm{ha}^{-1}$ ). In the northwest, however, weed dry weight was tremendously high, reaching an average of $1594 \mathrm{~kg}$ $\mathrm{ha}^{-1}$, and thus widely exceeding the national average of $1000 \mathrm{~kg} \mathrm{ha}^{-1}$ found in the 1960s (Mukula et al. 1969). The difference in weed dry weight between south and northwest is supported by Salonen et al. (2001b) who had found higher weed dry weight in the western part of central Finland compared with the southern mainland. The significantly higher crop density in the southern coastal region probably contributed to higher competitiveness of the crop and thus to lower weed abundance (Erviö 1972, Erviö 1983). While the level of weed infestation was clearly influenced by climate, edaphic factors and management, there was only a weak positive correlation between the duration of organic farming and weed abundance in the south, and no correlation at all in the northwest. Regardless of region, the investigated spring cereal crops differed widely from each other with respect to weed abundance.

\section{Conclusions}

Weed communities of organically cropped spring cereal stands in the southern and the northwestern coastal regions differed from each other with regard to species composition, frequency of occur- rence and abundance. Weed species frequencies and abundances in the coastal regions differed from the inland regions. By favouring populations of rare and threatened weed species, organic farming proved to be beneficial for species diversity.

The present level of weed occurrence in organically cropped stands of spring cereals in the coastal regions calls for target-oriented weed management over an extended time span as well as the integration of preventive, cultural and physical control measures. Due to different weed communities, different weed control measures have to be applied in the southern, and in the northwestern coastal region, respectively.

Acknowledgements. We thank the R. Erik Serlachius foundation for supporting the sampling, the Göran and Louise Ehrnrooth foundation for supporting the evaluation of data and Jukka Salonen for comments on the manuscript.

\section{References}

Albrecht, H. \& Bachthaler, G. 1989. Unkrautsamengehalte und Bodeneigenschaften von Ackerflächen in Bayern. Weed Research 30: 101-108.

Albrecht, H. \& Mattheis, A. 1998. The effects of organic and integrated farming on rare arable weeds on the Forschungsverbund Agrarökosysteme München (FAM) research station in southern Bavaria. Biological Conservation 86 : 347-356.

Bayer, 1992. Important crops of the world and their weeds. 2nd ed. Leverkusen, Germany: BAYER AG. 1682 p.

Becker, B. \& Hurle, K. 1998. Unkrautflora auf Feldern mit unterschiedlich langer ökologischer Bewirtschaftung. Zeitschrift für Pflanzenkrankheiten und Pflanzenschutz. Sonderheft 16: 155-161. (in German)

Blackshaw, R.E., Brandt, R.N., Janzen, H.H., Entz, T., Grant, C.A. \& Derksen, D. 2003. Differential response of weed species to added nitrogen. Weed Science 51 : 532-539.

Boström, U. \& Fogelfors, H. 1999. Type and time of autumn tillage with and without herbicides at reduced rates in Southern Sweden. Soil \& Tillage Research 50: 283293.

Bylterud, A. 1965. Mechanical and chemical control of Agropyron repens in Norway. Weed Research 5: 169-180.

Cardina, J., Regnier, E. \& Harrison, K. 1991. Long-term tillage effects on seed banks in three Ohio soils. Weed Science 39: 186-194.

Davies, D.H.K., Christal, A., Talbot, M., Lawson, H.M. \& Wright, G.McN. 1997. Changes in weed populations in the conversion of two arable farms to organic farming. 
In: Proceedings of the 1997 Brighton Crop Protection Conference - Weeds. Brighton, UK. p. 973-978.

Dock-Gustavsson, A.-M. 1997. Growth and regenerative capacity of plants of Cirsium arvense. Weed Research 37: 229-236.

Donald, W.W. 1990. Management and control of Canada thistle (Cirsium arvense). Reviews of Weed Science 5: 193-250.

Doucet, C., Weaver, S.E., Hamill, A.S. \& Zhang, Z. 1999. Separating the effects of crop rotation from weed management on weed density and diversity. Weed Science 47: 729-735.

Ellenberg, H., Weber, H.E., Düll, R., Wirth, W., Werner, W. \& Paulißen, D. 1991. Zeigerwerte von Pflanzen in Mitteleuropa. Scripta Geobotanica 18: 1-248.

El Titi, A. 1995. Ecological aspects of integrated farming. In: Glen, D.M. et al. (eds.). Ecology and integrated farming systems. New York, USA: John Wiley \& Sons. p. 243256.

Erviö, L.-R. 1972. Growth of weeds in cereal populations. Journal of the Scientific Agricultural Society in Finland 44: 19-28.

Erviö, L.-R. 1983. Competition between barley and annual weeds at different sowing densities. Annales Agriculturae Fenniae 22: 232-239.

Erviö L.-R. \& Salonen, J. 1987. Changes in the weed population of spring cereals in Finland. Annales Agriculturae Fenniae 26: 201-226.

Erviö, R., Hyvärinen, S., Erviö, L.-R. \& Salonen, J. 1994. Soil properties affecting weed distribution in spring cereal and vegetable fields. Agricultural Science in Finland 3: 497-504.

European Council 1991. European Council Regulation (EC) No. 2092/91. Available on the Internet: http://europa. eu.int/eur-lex/en/consleg/ main/1991/en_1991R2092_ index.html

European Council 1999. European Council Regulation (EC) No. 1804/1999. Available on the Internet: http://europa. eu.int/eur-Iex/pri/en/oj/dat/1999/I_222/I_ 22219990824en00010028.pdf

Finnish Meteorological Institute 2003. Climate data. Helsinki, Finland.

Fogelfors, H. 1977. Åkerogräs i Sverige. Lantbrukshögskolans meddelanden B 19. Uppsala, Sweden. 233 p. (in Swedish)

Freyer, B. 1991. Ökologischer Landbau - Planung und Analyse von Betriebsumstellungen. Ökologie \& Landwirtschaft 2. Weikersheim, Germany: Verlag Josef Markgraf. 229 p. (in German)

Frick, B. \& Thomas, A.G. 1992. Weed surveys in different tillage systems in southwestern Ontario field crops. Canadian Journal of Plant Science 72: 1337-1347.

Habel, W. 1954. Über die Wirkungsweise der Eggen gegen Samenunkräuter sowie die Empfindlichkeit der Unkrautarten und ihrer Altersstadien gegen den Eggvorgang. Dissertation. Hohenheim, Germany. 57 p. (in German)

Håkansson, S. 2003. Weeds and weed management on arable land. Wallingford, UK: CABI Publishing. $274 \mathrm{p}$.

Hald, A.B. 1999. Weed vegetation (wild flora) of long established organic versus conventional cereal fields in Denmark. Annals of Applied Biology 134: 307-314.
Hallgren, E. 1996. Occurrence of broad-leaved weeds on different soils in different crops in Sweden. Swedish Journal of Agricultural Research 26: 115-123.

Hämet-Ahti, L., Suominen, J., Ulvinen, T. \& Uotila, P. 1998. Retkeilykasvio (Field Flora of Finland). Helsinki, Finland: Finnish Museum of Natural History, Botanical Museum. 656 p. (in Finnish)

Heck, K.L.J., van Belle, G. \& Simberloff, D. 1975. Explicit calculation of the rarefaction diversity measurement and the determination of sufficient sample size. Ecology 56: 1459-1461.

Hyvönen, T. \& Salonen, J. 2001. Weed species diversity and community composition in cropping practices at two intensity levels - a six-year experiment. Plant Ecology 159: 73-81.

Hyvönen, T., Ketoja, E., Salonen, J., Jalli, H. \& Tiainen, J. 2003. Weed species diversity and community composition in organic and conventional cropping of spring cereals. Agriculture, Ecosystems and Environment 97: 131-149.

Information Centre of the Ministry of Agriculture and Forestry (Maa- ja metsätalousministeriön tietopalvelukeskus) 2003. Maatilarekisteri 2002 (Farm Register 2002). Helsinki, Finland. 130 p.

Jensen, E.S. 1986. Symbiotic $\mathrm{N}_{2}$ fixation in pea and field bean estimated by ${ }^{15} \mathrm{~N}$ fertilizer dilution in field experiments with barley as a reference crop. Plant and Soil 92: 3-13.

Jørnsgård, B., Rasmussen, K., Hill, J. \& Christiansen, J.L. 1996. Influence of nitrogen on competition between cereals and their natural weed populations. Weed Research 36: 461-470.

Kakriainen-Rouhiainen, S., Väisänen, J., Vanhala, P. \& Lötjönen, T. 2003. Mid-summer bare fallow effective in controlling perennial weeds. In: Niemeläinen, O. \& Topi-Hulmi, M. (eds.). Nordic agriculture in global perspective. Proceedings of the NJF's 22nd Congress. Tampere, Finland: Tampere University Print. p. 104.

Kees, H. 1962. Untersuchungen zur Unkrautbekämpfung durch Netzegge und Stoppelbearbeitungsmassnahmen unter besonderer Berücksichtigung des leichten Bodens. Dissertation. Hohenheim, Germany. 102 p. (in German)

Koch, W. 1959. Untersuchungen zur Unkrautbekämpfung durch Saatpflege und Stoppelbearbeitungsmassnahmen. Dissertation. Hohenheim, Germany. 123 p. (in German)

Krebs, C.J. 1999. Ecological methodology, Second edition. California, USA: Benjamin/Cummins. 620 p.

Kurki, M. 1982. Suomen peltojen viljavuudesta III. Helsinki, Finland. 181 p. (in Finnish, with English summary)

Leeson, J.Y., Sheard, J.W. \& Thomas, A.G. 2000. Weed communities associated with arable Saskatchewan farm management systems. Canadian Journal of Plant Science 80: 177-185.

Mäder, P., Fliessbach, A., Dubois, D., Gunst, L., Fried, P. \& Niggli, U. 2002. Soil fertility and biodiversity in organic farming. Science 296: 1694-1697.

Mahn, E.-G. 1988. Changes in the structure of weed communities affected by agro-chemicals - what role does nitrogen play? Ecological Bulletins 39: 71-73.

Mela, T. 1988. Luonnonmukainen peltoviljely Suomessa. 


\section{AGRICULTURAL AND FOOD SCIENCE}

Vol. 15 (2006): 166-182.

Viljelymenetelmät, rikkakasvit, peltojen viljavuus, sadot ja sadon laatu. English summary: Organic farming in Finland. Cultivation methods, weeds, soil fertility, yields and yield quality. University of Helsinki. Department of Plant Husbandry. Publications 16. Helsinki, Finland. $220 \mathrm{p}$.

Mukula, J., Raatikainen, M., Lallukka, R. \& Raatikainen, T. 1969. Composition of weed flora in spring cereals in Finland. Annales Agriculturae Fenniae 8: 59-110.

Mukula, J. 1974. Weed competition in spring cereal fields in Finland. Forskning og forsøk i lantbruket 25: 585-592.

Mukula, J. \& Rantanen, O. 1987. Climatic risks to the yield and quality of field crops in Finland. I. Basic facts about Finnish field crop production. Annales Agriculturae Fenniae 26: 1-18.

National Board of Agriculture (Maatilahallitus) 1991. Maatilatilastollinen vuosikirja 1990 (Yearbook of Farm Statistics 1990). Helsinki, Finland. 254 p.

Nykänen, A., Granstedt, A., Laine, A. \& Kunttu, S. 2000. Yields and clover contents of leys of different age in organic farming in Finland. Biological Agriculture and Horticulture 18: 55-66.

Pekrun, C. \& Lutman, P.J.W. 1998. The influence of postharvest cultivation on the persistence of volunteer oilseed rape. Aspects of Applied Biology 51: 113-118.

Plant Production Inspection Centre (Kasvintuotannon tarkastuskeskus) 2003. Luonnonmukainen maatalous 2002 - Tilastoja (Organic Farming 2002 - Statistics). Julkaisuja B2 Luomutuotantu 2/2003. Loimaa, Finland. $56 \mathrm{p}$.

Pyšek, P. \& Lepš, J. 1991. Response of a weed community to nitrogen fertilisation: a multivariate analysis. Journal of Vegetation Science 2: 237-244.

Rantzau, R., Freyer, B. \& Vogtmann, H. 1990. Umstellung auf ökologischen Landbau. Schriftenreihe des Bundesministers für Ernährung, Landwirtschaft und Forsten. Reihe A: Angewandte Wissenschaft 389. Münster-Hiltrup, Germany: Landwirtschaftsverlag GmbH. 153 p. (in German)
Rasmussen, K., Holst, N. \& Kristensen, I.S. 1998. Weeds at eight organic livestock farms - significant factors for weed dynamics 1989-1996. In: Danmarks Jordbrugsforskning. 15th Danish plant protection conference. Side effect of pesticides, weeds. Markbrug 2: 203-217. Foulum, Denmark. (in Danish)

Rassi, P., Alanen, A., Kanerva, T. \& Mannerkoski, I. (eds.). 2001. The 2001 red list of Finnish species. Ministry of the Environment and Finnish Environment Institute. Helsinki, Finland. Available on the Internet: http://www. vyh.fi/eng/environm/naturcon/threat/2000/2000.htm

Rydberg, N.T. \& Milberg, P. 2000. A survey of weeds in organic farming in Sweden. Biological Agriculture and Horticulture 18: 175-185.

Salonen, J. 1993. Weed infestation and factors affecting weed incidence in spring cereals in Finland - a multivariate approach. Agricultural Science Finland 2: 525536.

Salonen, J., Hyvönen, T. \& Jalli, H. 2001a. Weeds in spring cereal fields in Finland - a third survey. Agricultural and Food Science in Finland 10: 347-364.

Salonen, J., Hyvönen, T. \& Jalli, H. 2001b. Weed flora in organically grown spring cereals in Finland. Agricultural and Food Science in Finland 10: 231-242.

Sokal, R.R. \& Rohlf, F.J. 1995. Biometry. The principles and practice of statistics in biological research. 3rd edition. New York, USA: W.H. Freeman and Company. 887 p.

Svensson, R. \& Wigren, M. 1986. Observations on the decline of some farmland weeds. Memoranda Societas Pro Fauna Flora Fennica 62: 63-67.

van Elsen, T. 2000. Species diversity as a task for organic agriculture in Europe. Agriculture, Ecosystems and Environment 77: 101-109.

Vuorinen, J. \& Mäkitie, O. 1955. The method of soil testing in use in Finland. Agrogeological Publications 63: 144.

Zadoks, J.C., Chang, T.T. \& Konzak, G.F. 1974. A decimal code for the growth stage of cereals. Weed Research 14: 415-421. 
Riesinger, P. \& Hyvönen, T. Weed occurrence in coastal regions of Finland

\title{
SELOSTUS
}

\section{Rikkakasvien esiintyminen rannikkoalueiden luomukevätviljapelloilla}

\author{
Paul Riesinger ja Terho Hyvönen \\ Helsingin yliopisto ja Maa- ja elintarviketalouden tutkimuskeskus
}

Tutkimuksessa vertailtiin eteläisen (Itä-Uusimaa, Uusimaa, Varsinais-Suomi ja Ahvenanmaa) ja Pohjanmaan rannikkoalueiden luonnonmukaisesti viljeltyjen kevätviljapeltojen rikkakasviyhteisöjä. Alueet eroavat toisistaan maataloustuotannon erikoistumisen, ilmaston ja maaperän suhteen. Näiden tekijöiden odotettiin aiheuttavan eroja rikkakasviyhteisöjen lajimääriin sekä lajien esiintymisfrekvensseihin, tiheyksiin ja kuivapainoihin.

Sekä lajien kokonaismäärä että keskimääräinen lajimäärä olivat suurempia eteläisellä rannikkoalueella kuin Pohjanmaalla (33 vs. 26 ja 17,3 vs. 10,8). Eteläiseltä rannikkoalueelta löydettiin joitakin harvinaisia lajeja (esim. ruisunikko), ja joitakin yleisiä lajeja tai sukuja, kuten peltoemäkki ja peipit, tavattiin ainoastaan etelästä. Linnunkaalin, peltolemmikin, pihatattaren, peltosaunion ja virnojen tiheydet ja kuivapainot olivat suuremmat eteläisellä rannikkoalueella, kun taas juolavehnän, ukontat- tarien ja peltohatikan tiheydet ja kuivapainot olivat suuremmat Pohjanmaan rannikolla. Rikkakasvien kokonaistiheys ei eronnut tutkimusalueiden välillä (565 vs. 570 versoa $\mathrm{m}^{-2}$ ). Sen sijaan kokonaiskuivapaino oli suurempi Pohjanmaalla kuin eteläisellä rannikkoalueella (1594 vs. $697 \mathrm{~kg} \mathrm{ha}^{-1}$ ), mikä paljolti johtui suuresta juolavehnän määrästä Pohjanmaalla.

Ainoastaan eteläisellä rannikkoalueella rikkakasvitiheys vaihteli luomuviljelyn keston mukaan. Aiempiin kartoituksiin verrattuna typpeä suosivat rikkakasvilajit olivat runsaampia, kun taas nurmipitoisessa viljelykierrossa yleisten monivuotisten rikkakasvilajien runsaus oli alhaisempi. Tämä johtunee luomuviljelyn tehokkuuden noususta Suomessa. Rikkakasviyhteisöjen alueelliset ominaispiirteet pitäisi ottaa huomioon suunniteltaessa rikkakasvien torjuntaa. 
